\title{
Choosers and losers: The impact of government subsidies on \\ Australian secondary schools
}

Louise Watson

University of Canberra

Chris Ryan

Australian National University

\begin{abstract}
Wor over three decades, government subsidies have been a major source of funds for private schools in Australia. Private schools now enrol more than one-third of all students. Analysing administrative and participation data, we find that Australian private schools have used government subsidies to increase the quality of their services (that is, to reduce student:teacher ratios) rather than to reduce their fees. As a consequence, the socio-economic composition of private schools has remained above average while a higher proportion of public school students now come from low socio-economic status (SES) backgrounds. The data suggest that Australia's government funding scheme is ineffective in facilitating access to private schools for students from lower socio-economic backgrounds and has undermined the viability of public secondary schools.
\end{abstract}

\section{Introduction}

This paper reveals what parents do and what schools do when private schools are provided with recurrent funding from government to subsidise their operating costs. In Australia, since 1974, every student who has enrolled in an approved private school has attracted a government subsidy worth between $15 \%$ and $70 \%$ of average estimated student operating costs, determined on a needs basis (Watson, 2003). Described as 'unhelpfully complex and exceedingly opaque' (Dowling, 2008), the Australian schools funding system effectively creates a school education market where private schools in receipt of government funding compete with public schools for students.

This article examines trends in school enrolment and participation data, changes in tuition fees and trends in student:teacher ratios in private and public schools since the introduction of government operating subsidies for private schools. We reveal how private schools have used the additional resources provided by government and how the average socio-economic composition of schools in both the private and public sectors has changed. Finally, we discuss the impact of these changed enrolment patterns on schools and students, and the policy implications. 


\section{The Australian school funding system}

In Australia, the federal government provides a subsidy to assist students to attend the school of their choice in the private sector. Federal grants to private schools are supplemented by state government grants to a proportionate value of less than half the federal grant (Ministerial Council on Education, Employment, Training and Youth Affairs, 2004). Between 1974 and 1999, the Australian government's private school funding scheme allocated a government subsidy per student to each private school or system on the basis of the financial 'need' of the school or system, measured by its declared total level of private income. As most private school income was sourced from tuition fees, schools that charged high fees (mostly independent schools) received a lower per student grant than schools charging low tuition fees, most of which were Catholic schools. Since 2000, the level of federal funding has been linked more directly to the financial means of individual students' families (Watson, 2003).

Today, schools in the Catholic system receive combined (that is, federal and state) recurrent grants per student that are worth approximately $72 \%$ of their total income and source the remaining income from tuition fees and donations. Students attending independent schools attract total federal and state grants of varying proportions according to a measure of the socio-economic status (SES) of their students which amount to, on average, $40 \%$ of their total income (Ministerial Council on Education, Employment, Training and Youth Affairs, 2004). While some independent schools receive grants at the same level as schools in the Catholic system, the majority receive less than Catholic schools. The differentiated subsidies are paid in a lump sum to the school and all students attending a particular school are charged a common fee, regardless of their socio-economic status. There are both high-fee and low-fee schools in the independent sector. Public schools are, in theory, fully government funded, although many public schools receive 'voluntary' financial contributions from parents. In 2008, public schools enrolled $60 \%$ of all students at the secondary level (that is, Years 7 to 12), Catholic schools enrolled 22\% and the independent sector catered for 18\% (Australian Bureau of Statistics, 2008; Dowling, 2008; Watson, 2003, 2004).

The size of the private school sector in Australia has always been relatively large due to the high proportion of schools - traditionally at the primary levelsupported by the Catholic church. In 1965, 24\% of Australian school students were enrolled in the (then unfunded) private sector, of which $82 \%$ were in Catholic schools (Australian Bureau of Statistics, 1970). The private school sector's enrolment share declined steadily during the 1960s, precipitating demands for state aid to private schools (Albinski, 1966; Smart, 1978). The Catholic system's share of total enrolments fell from $19.5 \%$ in 1965 to $17 \%$ in 1973 . State government funding for private schools' operating costs was introduced in 1967, followed by federal funding in 1969 and then a major injection of federal funding in 1974. In the wake of the introduction of federal government funding, the decline in private school enrolment share was arrested, reaching a trough of $21.1 \%$ in 1977 and then beginning to climb thereafter as shown in Figure 1. 


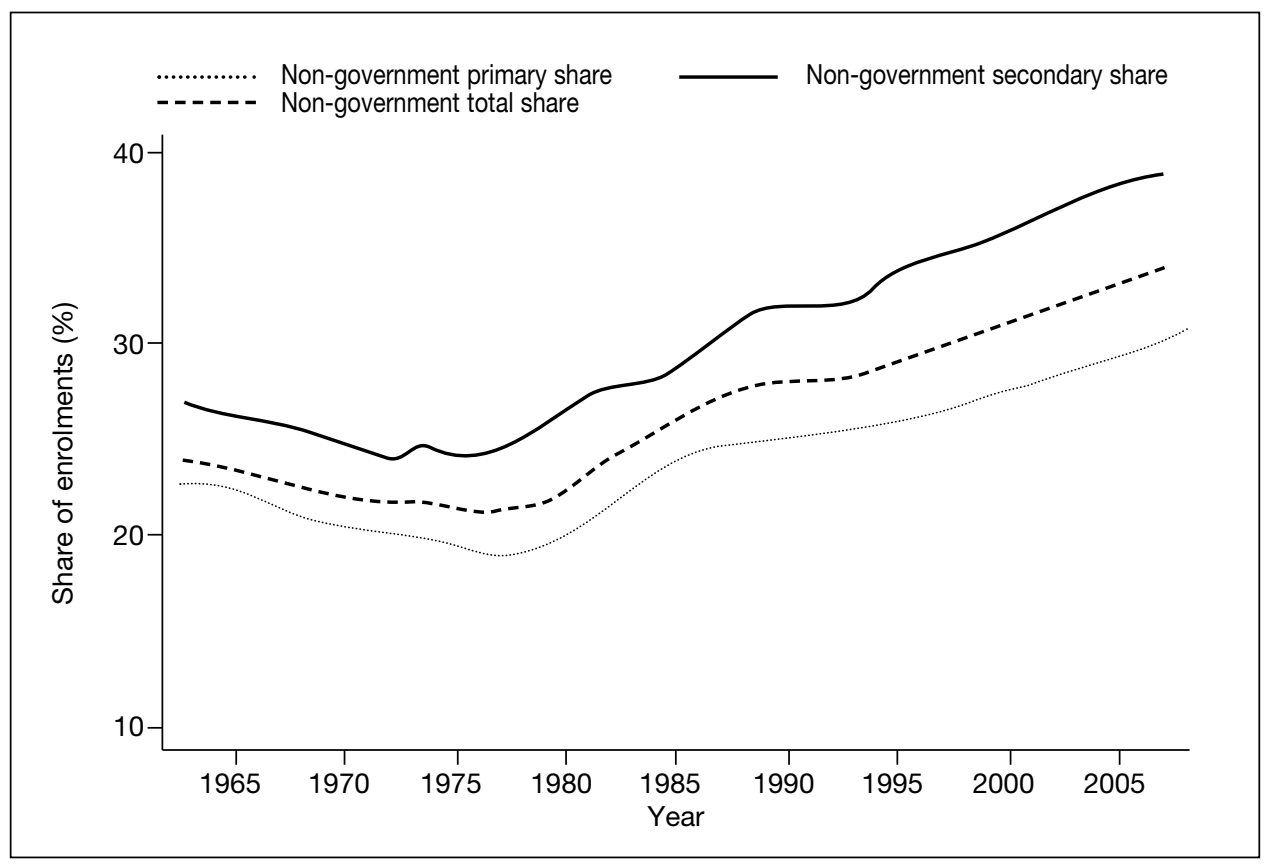

Figure I Private school enrolment share: 1963 to 2008

Source: Australian Bureau of Statistics (various years) Schools Australia, Catalogue No. 422I.0.

By 2008 the proportion of students in private schools was about 12 percentage points higher than the trough of the late 1970s. The increase in the private sector's enrolment share over this period was higher at the secondary level-closer to 15 percentage points. The private sector's enrolment increase over the period was not uniform, and growth in its share of secondary enrolments stagnated twice, during the recessions of the early 1980s and 1990s - both periods associated with strong increases generally in secondary school retention in Australia, which was concentrated in public schools. The growth in the private share of primary enrolments also slowed in the late 1980s, which suggests some other factor may have been at work, such as the impact of a federal policy that restricted the growth of new private schools - the New Schools Policy-between 1985 and 1996 (see Ryan \& Watson, 2004).

The federal government recurrent funding scheme introduced in 1974 remains the centrepiece of federal funding for private schools today. The recurrent funding scheme accounts for $94 \%$ of total federal outlays on private schools (Department of Education, Employment and Workplace Relations, 2009) and the real value of federal subsidies for students in private schools has increased steadily since the 1970s, as shown in Figure 2. This study focuses on secondary (high) schools because the successful completion of secondary school is a critical point for access to university. Entrance to most university courses, particularly those leading to prestigious professions such as law and medicine, are offered on the basis of a 
student's school achievement in Year 12. Thus the successful completion of secondary school is the principal means for determining the initial career outcomes of a large proportion of secondary students. This may contribute to the traditionally higher levels of private school enrolment at the secondary level in Australia.

The following section reveals how private schools have used the subsidies they have received from government through an examination of the relationship between tuition fees, student:teacher ratios and student enrolments.

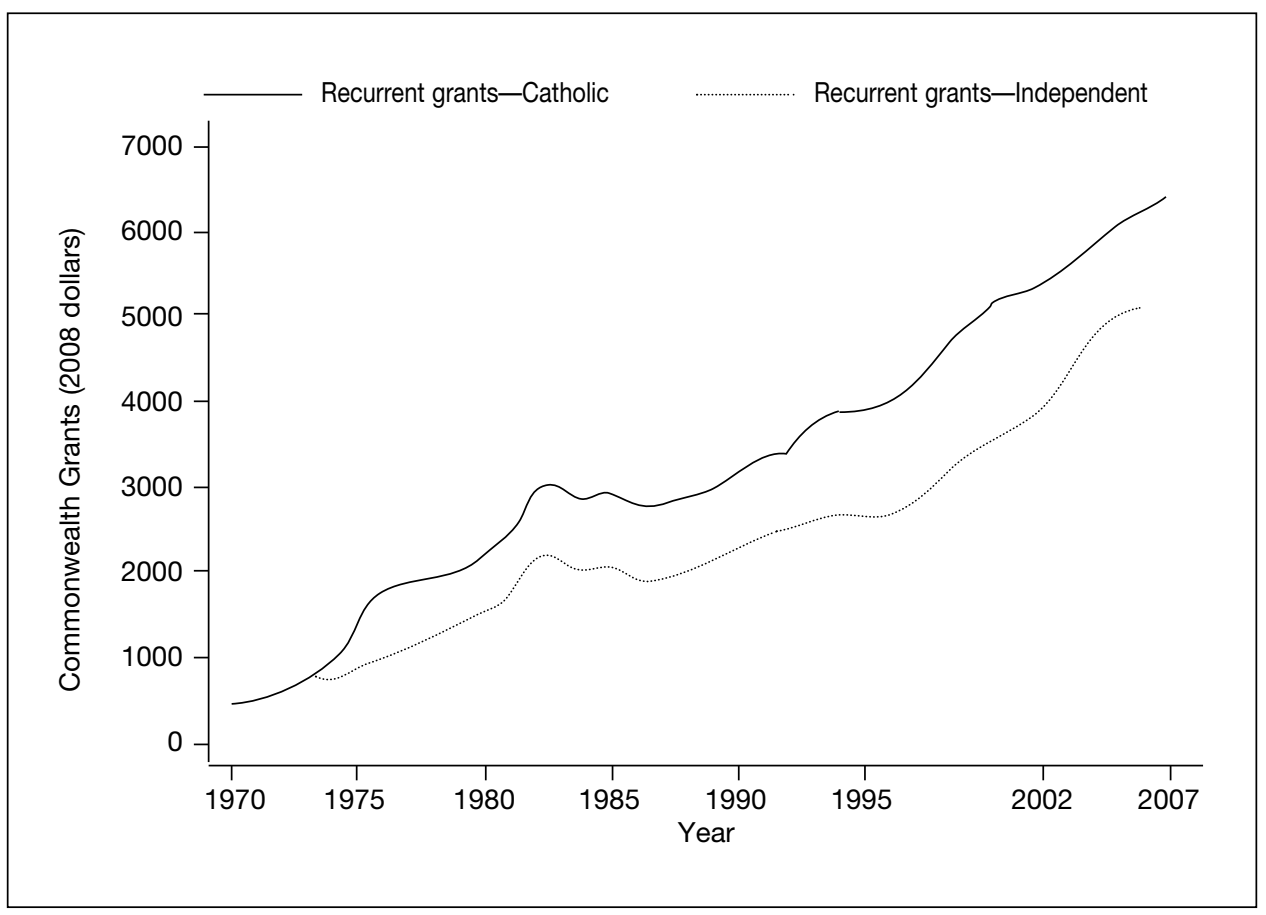

\section{Figure 2 Federal real per capita funding to private schools for secondary students: 1970 to 2007 (\$2008)}

Note: Prices deflated by the Consumer Price Index published by the Australian Bureau of Statistics, Consumer Price Index, Australia Catalogue No. 6401.0

Sources: Commonwealth Schools Commission (1975), Report for the triennium 1976-78, Canberra: AGPS; Commonwealth Schools Commission (1979), Australian students and their schools, Canberra: AGPS;

Commonwealth Schools Commission (1984), Australian school statistics, Ist edn, Canberra: AGPS;

Department of Education, Commonwealth (1985), Statistical Bulletin: Non-government schools, students and staff, Ist edn; Department of Employment, Education and Training, Commonwealth (1987), Schooling in Australiastatistical profile 1987, Canberra: AGPS; Department of Employment, Education and Training, Commonwealth (1989), Schooling in Australia-statistical profile no. 2, 1989, Canberra: AGPS; Karmel, P. (Chair) (1973), Schools in Australia: Report of the Interim Committee for the Australian Schools Commission, Canberra: AGPS; Ministerial Council on Education, Employment, Training and Youth Affairs, National report on schooling in Australia, various years, Melbourne: Curriculum Corporation; Ruby, A., Wells, L., \& Wildermuth, C. (1995), Choice, market theory and education: What are we talking about? Occasional Paper No. 19, Australian College of Education, Canberra; unpublished data from 1993 to 2002 on which the National Report estimates are produced, provided by the Commonwealth Department of Education, Science and Training. 


\section{Trends in enrolments, tuition fees and student: teacher ratios}

When the private sector's enrolment data are disaggregated by subsector, it would appear that charging relatively high tuition fees is not a barrier to growth. In 2002, average fees in the Catholic school system were almost $\$ 2500$ per annum, compared with more than $\$ 6000$ in the independent sector. Fees in the Catholic system have more than doubled from the early 1970s in real terms, with smaller growth evident in tuition fees in the independent sector: $160 \%$ increase in Catholic tuition fees compared with $70 \%$ in independent tuition fees. (These increases in real fees exceed increases in real incomes over the same period: per capita real household disposable income increased by 46\% between 1972 and 2002, while real male average weekly earnings increased by $26 \%$.) There has been substantial growth in real fees in both the Catholic and independent sectors from the mid-1980s. While Williams (1985) found that aggregate private sector fees fell initially after the increase in operating grants to the early 1980s, estimates attributed to him in Ruby, Wells and Wildermuth (1995) include the same increase in fees from the mid-1980s as found here: around 5\% per annum in real terms in the Catholic sector and over $2 \%$ in the independent sector. The growth in real fees paused during the early 1990s, before returning to the previous rates after 1995 (Ryan \& Watson, 2004). As indicated in Figure 3, enrolments in independent schools, which generally charge higher fees, have grown at a faster rate than enrolments in Catholic schools since 1977. Thus while private tuition fees have increased since 1972, in both Catholic

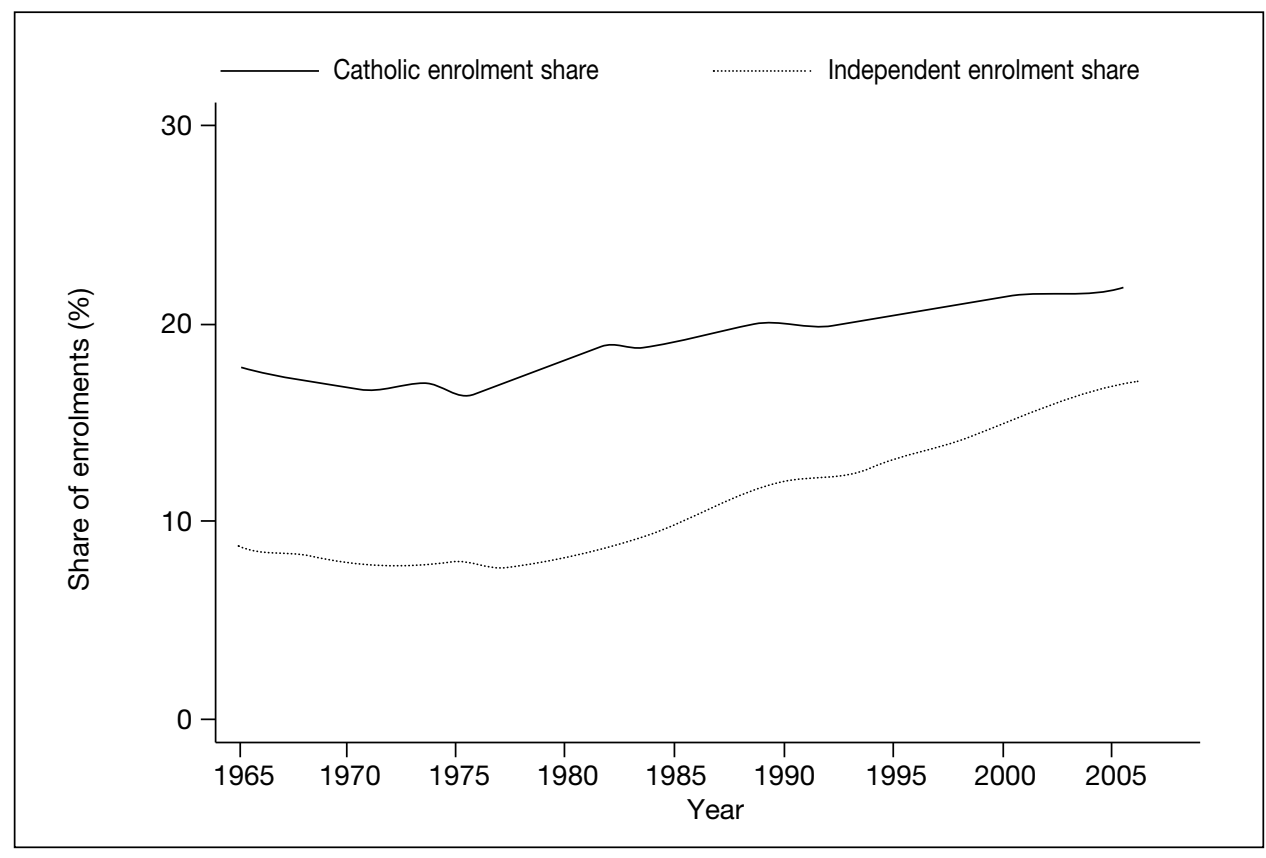

Figure 3 Private high (secondary) school enrolment share 1965 to 2008

Source: Australian Bureau of Statistics (various years) Schools Australia, Catalogue No. 4221.0 


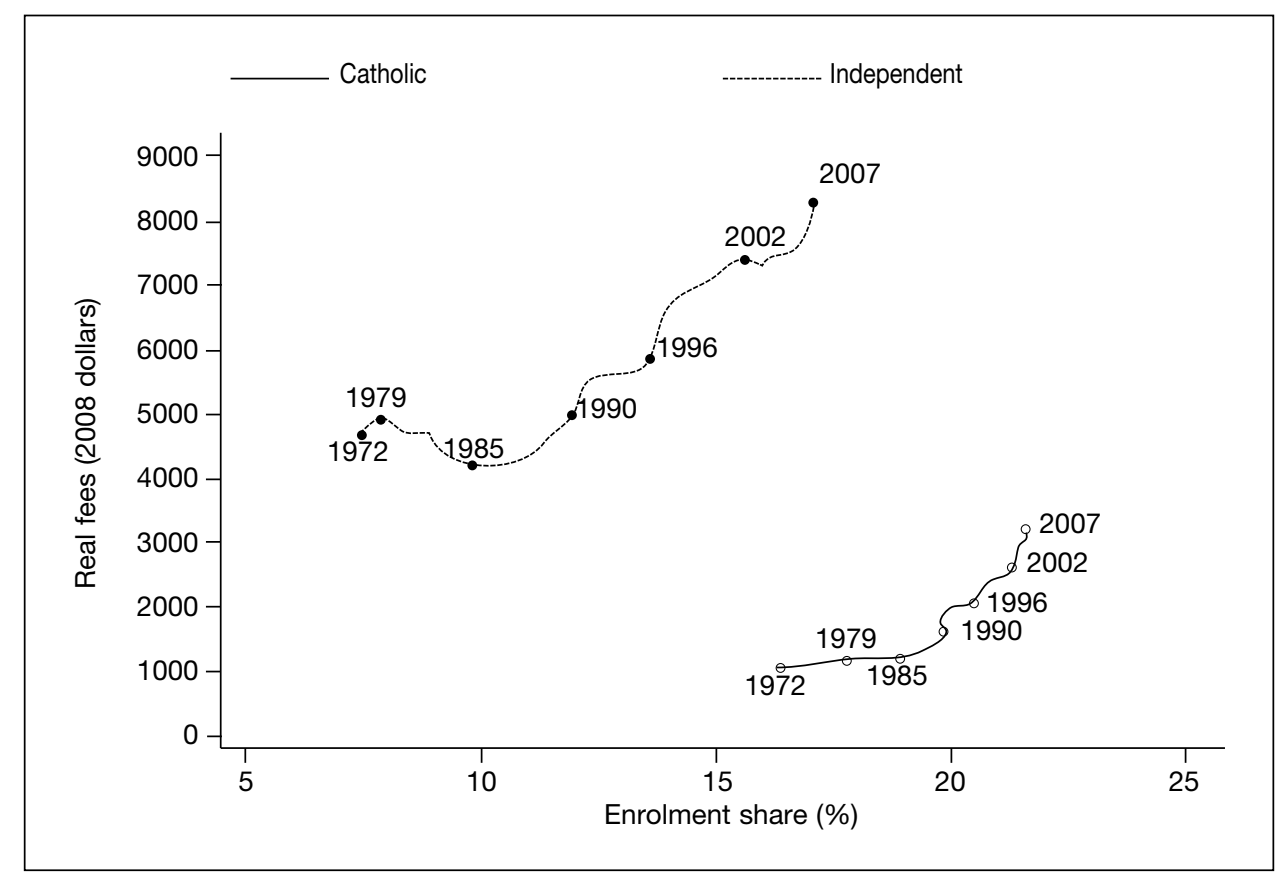

\section{Figure 4 Private secondary school enrolment shares and real fees, 1972 to 2007}

Note: Prices deflated by the Consumer Price Index published by the Australian Bureau of Statistics, Consumer Price Index, Australia Catalogue No. 640I.0

Sources: Australian Bureau of Statistics (various years) Schools Australia, Catalogue No. 422I.0; Commonwealth Schools Commission (1975), Report for the triennium 1976-78, Canberra: AGPS;

Commonwealth Schools Commission (1979), Australian students and their schools, Canberra: AGPS; Commonwealth Schools Commission (1984), Australian school statistics, Ist edn, Canberra: AGPS;

Department of Education, Commonwealth (1985), Statistical Bulletin: Non-government schools, students and staff, Ist edn; Department of Employment, Education and Training, Commonwealth (1987), Schooling in Australiastatistical profile 1987, Canberra: AGPS; Department of Employment, Education and Training, Commonwealth (1989), Schooling in Australia-statistical profile no. 2, 1989, Canberra: AGPS; Karmel, P. (Chair) (1973), Schools in Australia: Report of the Interim Committee for the Australian Schools Commission, Canberra: AGPS; Ministerial Council on Education, Employment, Training and Youth Affairs, National report on schooling in Australia, various years, Melbourne: Curriculum Corporation; Ruby, A., Wells, L., \& Wildermuth, C. (1995), Choice, market theory and education: What are we talking about? Occasional Paper No. 19, Australian College of Education, Canberra; unpublished data from 1993 to 2002 on which the National Report estimates are produced, provided by the Commonwealth Department of Education, Science and Training.

and independent schools, this has not affected demand for private schools, except during the economic recession of the early 1990s. (It should be noted that these changes occurred in the context of a general increase in the real value of household incomes as well as an increase in two-income households, particularly at the upper end of the socio-economic distribution.)

Increases in school tuition fees did not have a negative impact on private school enrolments, particularly in the independent sector. This is illustrated in Figure 4, which depicts trends in private school enrolment shares and real fees jointly through time. In the independent sector, both fee increases and enrolment 
share increases were modest until the mid-1980s, but increased consistently thereafter. In the Catholic sector, enrolment shares increased most during the period of fee stability in the early 1980s, but slowed once fees in that sector began to rise.

In the Australian schools funding system, grants are provided to private schools to meet operating expenses under the recurrent grants scheme. A separate capital grants scheme assists private schools with building new facilities. The federal government's guidelines for the recurrent grants scheme specify that recurrent funding must be spent for operational purposes in the calendar year in which it is allocated. The main operating expense for all schools is the salaries and on-costs of teaching staff. Some $78 \%$ of private school total operating expenditure (excluding capital expenditure and debt servicing) is spent on teachers' salaries and related staff expenses (Ministerial Council on Education, Employment, Training and Youth Affairs, 2004). Thus if a private school decides not to reduce its tuition fees, the additional resources from federal grants are most likely to be spent on employing more teachers. Our data suggest that the additional resources available to private schools from steady increases in government funding and rising tuition fees since the 1970s have contributed to improvements in student:teacher ratios in both Catholic and independent schools. As the Catholic school system charges lower fees on average than independent schools, student:teacher ratios still remain higher in Catholic schools than in independent schools, as shown in Figure 5.

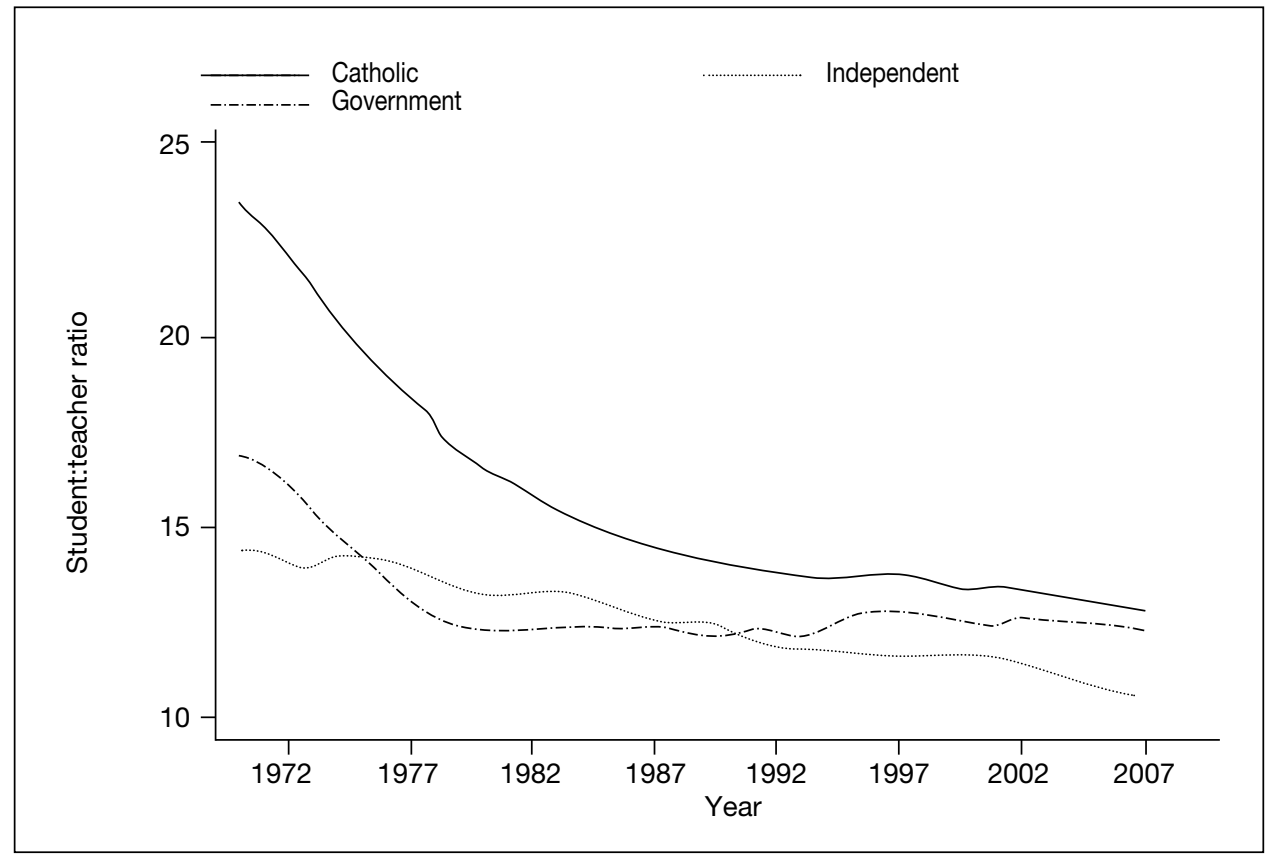

Figure 5 Student:teacher ratios in public and private secondary schools, 1970 to 2008

Note: Vertical axis shows the number of students per teacher.

Source: Australian Bureau of Statistics (various years) Schools Australia, Catalogue No. 422I.0. 
Any discussion of the relationship between improved student:teacher ratios and shifts in student enrolments to the private sector must take into account the relative student:teacher ratios in public schools. Student:teacher ratios in public schools also improved during the 1970s, but then remained constant over the 1980s and deteriorated slightly during the 1990s. As a result of the strong improvement in student:teacher ratios in the public schools in the 1970s, the private sector's student:teacher ratios did not improve relative to public schools until the early 1980s, but demonstrated a steady relative improvement thereafter. The relationship between changes in student:teacher ratios in private schools relative to student:teacher ratios in public schools is illustrated in Figure 6. The purpose of the illustration is to see if the improvement in the student:teacher ratios for the Catholic and independent sectors from the late 1970s and early 1980s relative to public schools had any apparent impact on the enrolment shift from public to private schools over this period. As shown in Figure 6, improvements in private school student:teacher ratios relative to public schools after 1979, were associated with steady improvements in the enrolment share of both Catholic and independent schools.

A study by Williams (1985) suggested that the balance between fee reduction and quality improvement strategies adopted in private schools has influenced the type of student who has transferred from the public to private school sector since

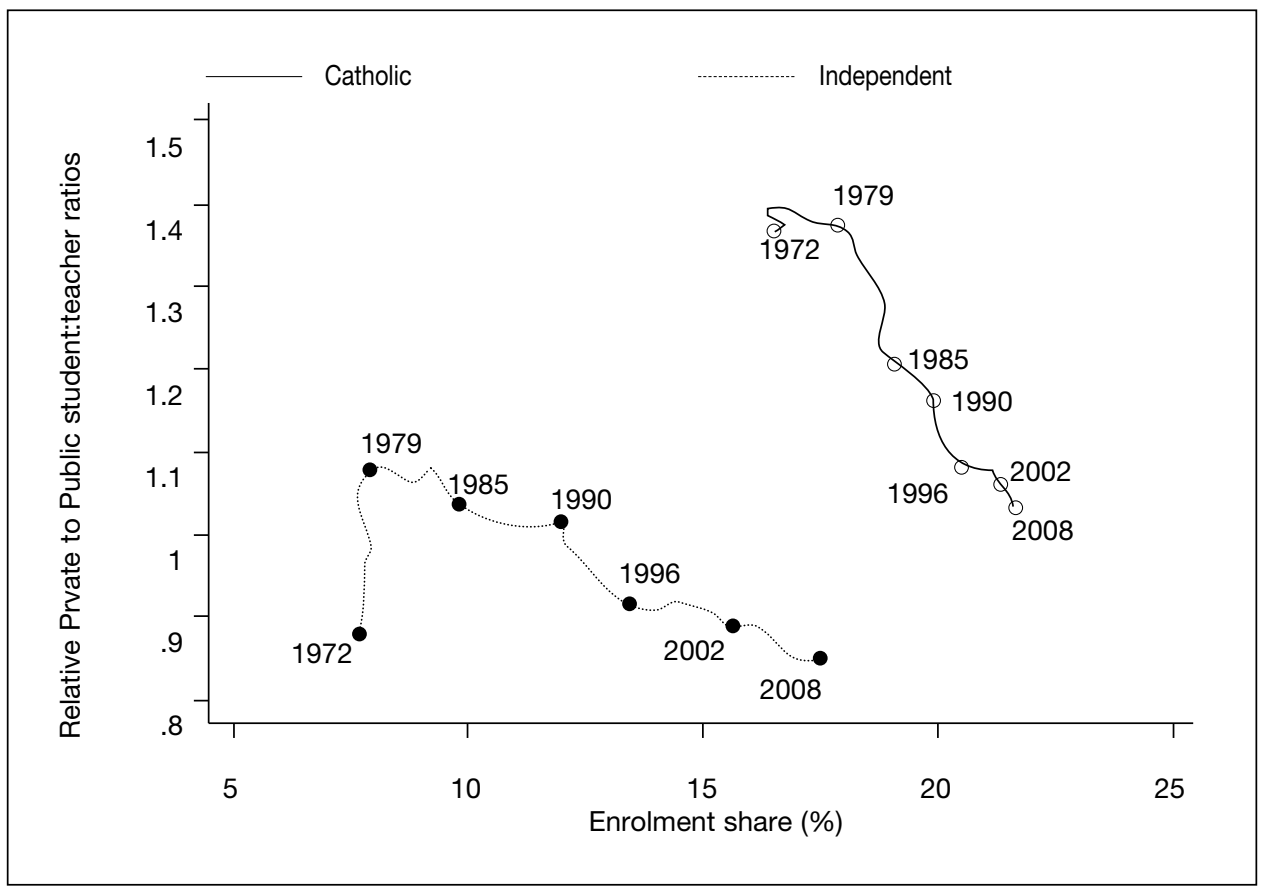

Figure 6 Private secondary school enrolment shares and student:teacher ratios relative to public schools: 1972 to 2008

Source: Australian Bureau of Statistics (various years) Schools Australia, Catalogue No. 422I.0. 
the 1970s. Williams's analysis of the determinants of the private school enrolment share from 1963 to 1983 in Australia found that student:teacher ratios in the private sector had a positive effect on private schools' enrolment share, while increases in the public sector's student:teacher ratios had a negative impact on the private enrolment share. The private school enrolment share also rose with increased levels of government grants and contributed services. Williams found that improved student:teacher ratios in the private sector (funded by government grants) had a more positive impact on the private sector's enrolment share than increases in school tuition fees (Williams, 1985).

The evidence presented above suggests that income from government subsidies and rising tuition fees has enabled private schools to improve their student: teacher ratios substantially, to a position where the student:teacher ratios in Catholic schools are almost equal to public schools and the ratio in independent schools is better than in public schools. As the student:teacher ratio in public schools also improved between 1972 and 1980, the private sector's ratio improved relative to public schools only since the early 1980s. And this period marks the beginning of an increase in the enrolment share of private schools, implying that the improvement in the student:teacher ratios of private schools (relative to public schools) since the 1970s is associated with an increase in their enrolment share.

Responsibility for this outcome does not rest entirely with private schools. In providing subsidies to private schools, the federal government stated that its intention was to improve the student:teacher ratios relative to public schools, particularly in the Catholic school sector (Karmel, 1973). Throughout the 1980s, the federal government argued that private schools should not use subsidies to replace fee income and encouraged them to increase their tuition fees annually to reflect general price movements (Department of Employment, Education and Training, 1989). By the mid-1990s, after two decades of increases in both subsidies and tuition fees coupled with continuing strong demand for private schools, such exhortations were no longer necessary.

In summary, strong real increases in private school tuition fees since 1972 have had no apparent negative impact on the enrolment share of either Catholic or independent schools, except during the few years of the economic recession in the 1980s and early 1990s. In stable economic conditions, improvements in student: teacher ratios in private schools relative to public schools appear to have had a positive impact on demand for private schooling irrespective of increases in the cost of tuition.

\section{Changes in the social background of students in public and private schools}

In this section we examine changes in the social background of students who attend private schools using data from three cohorts of students. The cohorts were in school in 1975, 1995 and 2006, respectively. The data are drawn from the Youth in Transition 1961 birth cohort (the 1975 school cohort) and the Longitudinal Surveys of Australian Youth cohorts of 1995 and 2006 (the 1995 and 2006 cohorts, respectively). The 1975 cohort involved 6260 students from 264 schools; the 1995 
cohort 13,613 students from 286 schools; the 2006 cohort 14170 students from 356 schools. These sample sizes represented about $2.5 \%$ of 14 -year-olds at secondary school in Australia in 1975, 5.5\% of Year 9 students in 1995 and 6\% of 15-year-olds at school in 2006. In the first two cohorts, approximately $12 \%$ of schools with secondary school students were surveyed, and a somewhat higher proportion in the third cohort. The 1975 and 2006 cohorts obviously allow us to draw out long-term trends in student enrolment patterns between government and private schools, while the 1995 cohort allows us to see whether the strong growth in government funding since 1996 (Figure 2) affected enrolment shares across the social background distribution.

The socio-economic (SES) score of an individual was calculated as a weighted average of the education levels and occupations of their parents. The weights were based on the parameters of a regression equation where the dependent variable was the individual's desired or anticipated future occupation, identified when they were still teenagers. SES scores derived in alternative ways showed qualitatively similar changes between the two cohorts. The average SES scores of individuals who attended different school types in the three cohorts are presented in the lower half of Table 1.

The upper half of Table 1 shows the enrolment shares of the different school types and the way they changed between the cohorts. The enrolment share of private secondary schools increased by 16 percentage points between the first and last cohorts, with independent schools picking up a little more than half of that increase and Catholic schools a little less than half. While the average socio-economic status of independent and Catholic schools declined, this should be interpreted in light of their increased enrolment share. As the independent sector received the largest increase in enrolment share, its average socio-economic status, while still the highest of all sectors, declined, yet it remains substantially higher than the SES of the public school population.

The average SES of students is highest in all cohorts for those who attend independent schools, followed by Catholic schools and public schools. The interpretation of these SES scores is as follows: in 1975, the average student at an independent school had an SES background that was higher than $73 \%$ of students. The pattern of school-type enrolment share by SES is similar for the 1995 data as confirmed by other studies, such as the analysis of enrolment shares by SES using the 1996 Australian Census in Mukerjee (1999) and by family income using the 2001 Census in Preston (2003).

In Preston's analysis of secondary enrolments in low, middle and high family income groups (categories that split secondary school students into groups of roughly equal size), the proportion attending government schools in these income groups were 76,67 and $48 \%$. The proportions in the other sectors were as follows: Catholic: 15, 22 and 27; independent: 9, 12 and 25. Splitting Mukerjee's analysis into three groups (lowest three SES quartiles, middle four quartiles, top three quartiles) provided the following enrolment shares: government: 78, 67 and 50; Catholic: 17, 22 and 24; independent: 5, 11 and 27. If we split the 1995 data into three groups of equal size, consisting of low, middle and high SES groups, we obtain 
Table I Secondary school enrolment shares and average SES scores by school type in 1975, 1995 and 2006

\begin{tabular}{|c|c|c|c|c|}
\hline School type & 1975 & 1995 & 2006 & $\begin{array}{c}\text { Change } \\
1975 \text { to } 2006\end{array}$ \\
\hline \multicolumn{5}{|c|}{ Enrolment share (\%) } \\
\hline Public & 77.7 & 67.2 & 61.7 & -16.0 \\
\hline Private & 22.3 & 32.8 & 38.3 & 16.0 \\
\hline Catholic & 15.1 & 20.2 & 22.1 & 7.0 \\
\hline Independent & 7.2 & 12.7 & 16.2 & 9.0 \\
\hline \multicolumn{5}{|c|}{ Average socio-economic status (SES) } \\
\hline Public & 0.463 & 0.447 & 0.447 & -0.015 \\
\hline Private & 0.630 & 0.599 & 0.586 & -0.044 \\
\hline Catholic & 0.583 & 0.568 & 0.524 & -0.058 \\
\hline Independent & 0.729 & 0.648 & 0.670 & -0.058 \\
\hline
\end{tabular}

Note: Individual elements may not sum to totals due to rounding.

Sources: Youth in Transition 196I birth cohort; Longitudinal Surveys of Australian Youth 1995, Year 9, Australian Council of Educational Research and National Centre for Vocational Education Research, unpublished.

the following enrolment shares: government: 77, 68 and 50; Catholic: 15, 22 and 27; independent: 8, 10 and 23. The enrolment share patterns across the three different data sets using three different SES or income measures are similar at this level of aggregation, other than for the highest SES group.

We have not found any directly comparable analyses for the patterns in the 1975 data but re-analysis of data contained in Radford and Wilkes (1975:60) of the fathers' occupations of school leavers by school-type suggests a similar pattern of school type enrolment share by SES in their data to the data we use here. Specifically, the Catholic enrolment share did not vary much across the SES distribution; the government school share was similar in the low and middle SES groups, but substantially lower in the high SES group, where the independent school share was greater.

As indicated in Table 1, the average SES of students at public schools fell between 1975 and 2006 by 1.5 percentage points, while the average SES of students at private schools decreased by 4.4 percentage points. The private decrease was composed of similar decreases in the average SES of students at both Catholic schools and independent schools. (All of these changes were significant at the $5 \%$ level.) These changes suggest that the students who transferred from public schools were above average-SES students for the public system (and hence tended to be from the top half of the SES distribution, given its 1975 average student SES of 0.463). At the same time, those who entered private schools tended to have lower SES backgrounds than the typical private school student in the 1975 cohort.

To help identify where in the SES distribution the transfer of students from the public to the private sectors took place, Table 2 shows the change in enrolment shares of the three sectors between the two cohorts by SES decile. The drift away from public schools to both the Catholic and independent sectors is somewhat 
more pronounced in deciles 5 to 10 than in the first four deciles. That is, the change in enrolment shares was larger in the top half of the SES distribution. This concentration was more pronounced between 1975 and 1995 than over the whole period. Between 1995 and 2006, the loss in enrolment share was similar in the top and bottom halves of the distribution, though the sectors that gained share differed: the lost public school share went predominantly to Catholic schools in the bottom half of the distribution and independent schools in the top half.

To illustrate what these changes have meant for public school enrolments across the SES distribution, we present the figures in Table 2 in graphic form in Figure 7. It shows the change in the enrolment share between the cohorts by individual SES ranking. Between 1975 and 1998, the enrolment share of public schools fell by 16 percentage points in the (smoothed) data. Almost $60 \%$ of that decline took place in the top half of the distribution in the smoothed data in Figure 7 and in the actual data in Table 2. The public school enrolment share fell in excess of 20 percentage points between the 50th and 70th percentiles and in excess of 10 percentage points between the 70th and 90th percentiles. These estimates highlight the point made already in Table 2: that the students who were lost from public schools tended to come from the middle to top sections of the SES distribution.

To summarise, the average SES of students in public secondary schools fell by 1.5 percentage points between 1975 and 2006 while the average SES of students in private schools decreased by 4.4 percentage points. Thus although the estimated secondary enrolment share of private schools increased by 16 percentage points over the period, the relative SES of private school students compared to public school students changed little over the period. The average SES of private school students was about 17 percentage points higher than public school students in 1975 and 15 points in 2006. These figures mask important shifts in the compositions of the student populations in each sector. The students who transferred from public

Table 2 Changes in high (secondary) school enrolment shares by sector and SES decile between 1975 and 2006

\begin{tabular}{cccc}
\hline SES decile & Public & Catholic & Independent \\
\hline 1 & $-0.091 \ddagger$ & $0.067 \ddagger$ & $0.024 \ddagger$ \\
2 & $-0.168 \ddagger$ & $0.110 \ddagger$ & $0.058 \ddagger$ \\
3 & $-0.125 \ddagger$ & $0.096 \ddagger$ & $0.029 \ddagger$ \\
4 & $-0.114 \ddagger$ & $0.057 \ddagger$ & $0.057 \ddagger$ \\
5 & $-0.227 \ddagger$ & $0.117 \ddagger$ & $0.110 \ddagger$ \\
6 & $-0.236 \ddagger$ & $0.120 \ddagger$ & $0.116 \ddagger$ \\
7 & $-0.212 \ddagger$ & $0.069 \ddagger$ & $0.142 \ddagger$ \\
8 & $-0.133 \ddagger$ & 0.027 & $0.106 \ddagger$ \\
9 & $-0.188 \ddagger$ & $0.062 \ddagger$ & $0.126 \ddagger$ \\
10 & $-0.086 \ddagger$ & $-0.038 *$ & $0.124 \ddagger$ \\
Total & $-0.160 \ddagger$ & $0.070 \ddagger$ & $0.090 \ddagger$ \\
\hline
\end{tabular}

$*, \dagger$ and $\ddagger$ indicate significance at the 1,5 and $10 \%$ levels respectively

Sources: Youth in Transition 196I birth cohort and the Longitudinal Surveys of Australian Youth 2006,

cohort, Australian Council for Educational Research and National Centre for Vocational Education Research, unpublished. 


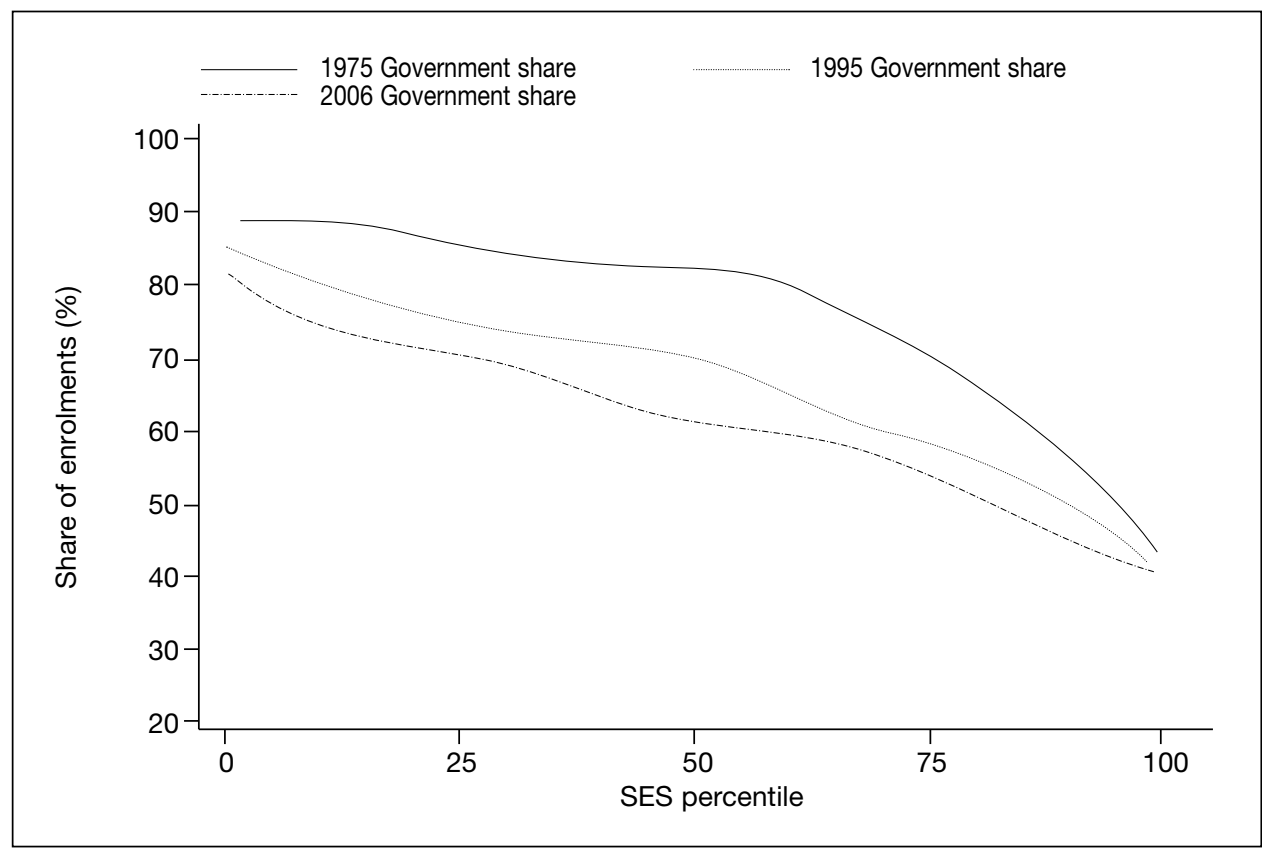

Figure 7 Probability of public secondary school enrolment by SES: 1975, 1995 and 2006

Sources: Youth in Transition 196I birth cohort and the Longitudinal Surveys of Australian Youth 1995 and 2006 cohorts, Australian Council for Educational Research and the National Centre for Vocational Education Research, unpublished.

schools to private schools over the period tended to be from the middle to top sections of the SES distribution. They were from above average-SES backgrounds relative to the 1975 public school population but below the average SES of the 1975 private school population. Almost $60 \%$ of the decline in public school enrolments between 1975 and 2006 occurred in the top half of the SES distribution.

\section{Changes in the average socio-economic status of public and private schools}

As we noted in the previous section, the public school sector lost students from the middle to top end of its SES distribution to private schools between 1975 and 2006, but these students were generally of a lower SES than the private school students of 1975. Thus the drift of students from public to private schools also had the effect of lowering the average SES of the private school sector, from 0.630 in 1975 to 0.579 in 2006 (compared to 0.463 in 1975 and 0.449 in 2006 for public schools). This section examines how the drift of students from public to private schools has influenced the average SES of schools in each sector, in relation to the SES of individual students. We are interested in two questions:

- how much has the average SES of the schools in each sector changed and how much has it varied with an individual's own SES level? 
- has the relationship between an individual's SES and average school SES changed over time in the sectors?

The first two questions are answered in Figure 8, which shows the (smoothed) average SES of the school that students from each level of the SES distribution attended in each sector in 2006. In other words, it shows that a student from a family at the 75th percentile of the SES distribution in the independent sector is most likely to attend a school with an average SES of 0.65. In comparison, a student from a family at the 75th percentile of the SES distribution in the public school sector is most likely to attend a school with an average SES of about 0.50.

Figure 8 also illustrates that, generally, there is a positive relationship in all three sectors - in 2006 students tended to go to schools with other individuals from similar social backgrounds, a relationship that appears to be broadly similar across the sectors. In all sectors, an individual at the top of the SES distribution attends a school with an average SES level at least 30 percentage points higher than an individual at the bottom of the SES distribution. But only individuals at the very top of the SES distribution in the public system tended to go to schools whose average SES was greater than 0.5 in 2006. That is, all but individuals from the top SES quartile in the public system tend to go to schools with students predominantly from below average SES backgrounds whereas this is less pronounced in the Catholic and independent sector.

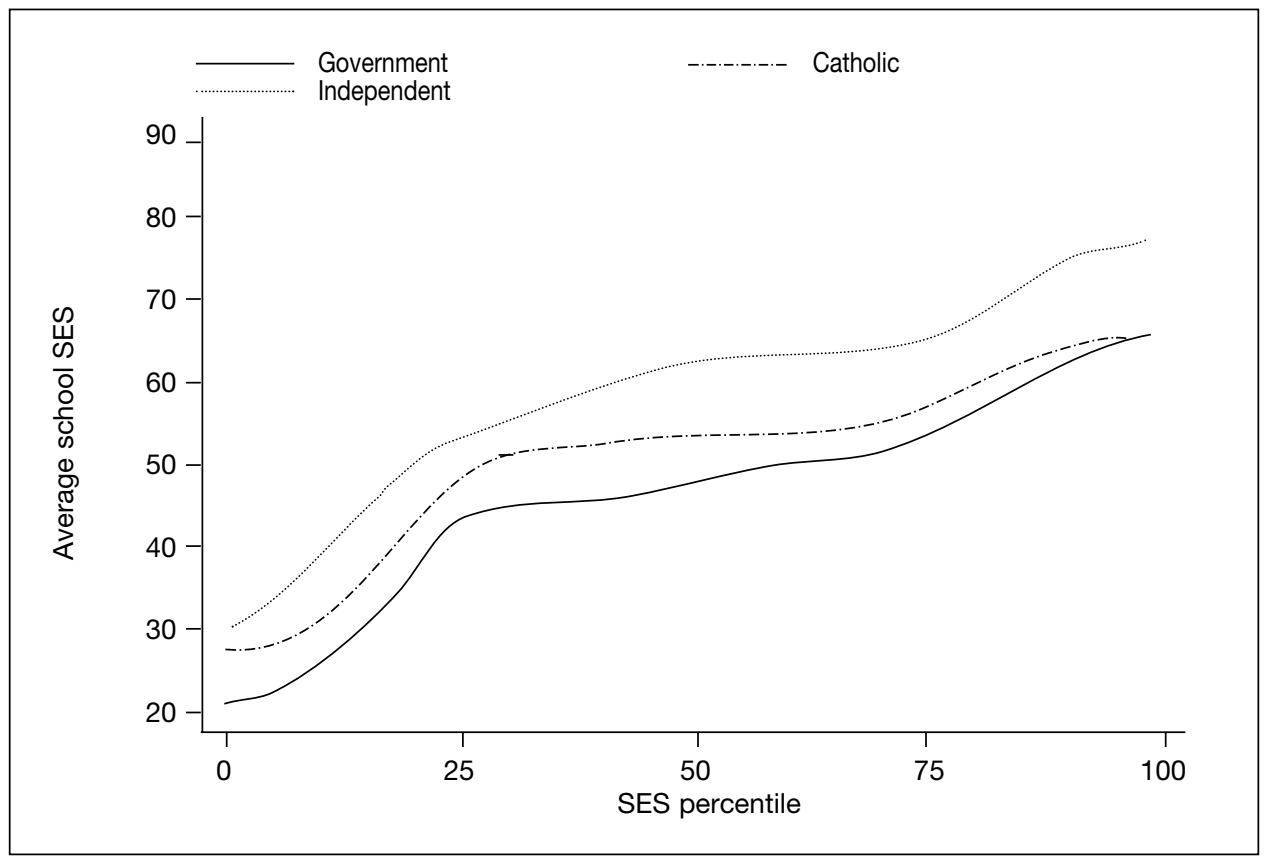

Figure 8 Average SES in secondary schools by sector by individual SES ranking, 2006

Sources: Longitudinal Surveys of Australian Youth 2006 cohort, Australian Council for Educational Research and National Centre for Vocational Education Research, unpublished. 


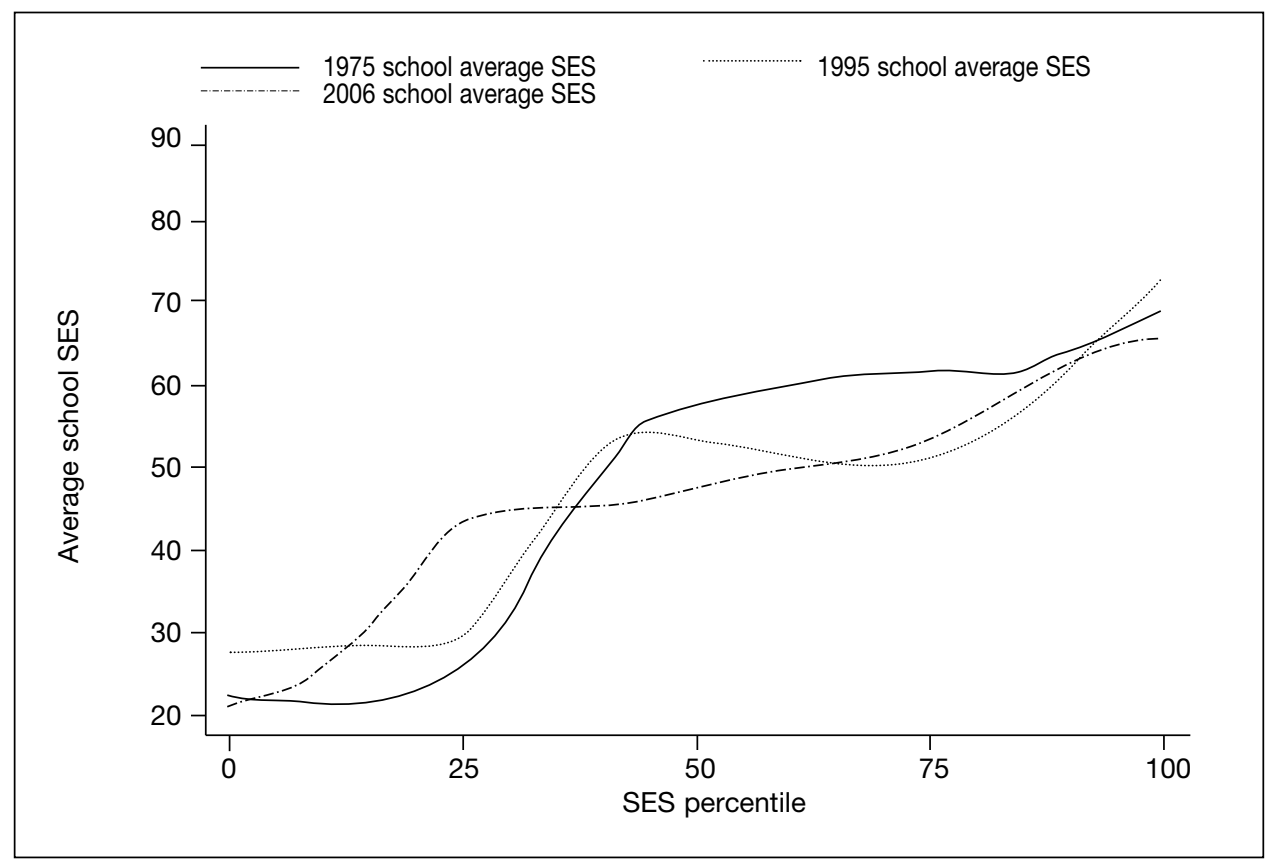

\section{Figure 9 Average SES in public secondary schools by individual SES ranking, 1975, 1995 and 2006}

Sources: Youth in Transition $196 \mathrm{I}$ birth cohort and the Longitudinal Surveys of Australian Youth 1995 and 2006 cohorts, Australian Council for Educational Research and the National Centre for Vocational Education Research, unpublished.

The final question was whether the relationships in the sectors between individual SES and average school SES have changed over time. We have examined this in all three sectors and found that the changes in the position of the average school SES curves between 1975 and 2006 in the Catholic and independent sectors are similar across the SES distribution. In other words, the curves in both sectors in 1975 are similar to those shown for 2006 in Figure 8, except that they moved down between 1975 and 2006. The change in the relationship between individual SES and average school SES in the public sector followed a different pattern, which is shown in Figure 9. In the public sector, as shown in Figure 9, the average school SES of those at the very top of the SES distribution changed very little between 1995 and 2006. For most public school students in the lower half of the individual SES distribution, their average school SES increased between 1975 and 2006 but, for public school students between the 40th and the 80th percentiles, the average SES of their school fell by up to 15 percentage points between 1975 and 2006. In 1975 , students from the 60th percentile in the public system tended to go to schools with students with similar average SES backgrounds to other students in the top half of the distribution, other than those at the very top of the SES distribution. From 1995 through to 2006, that was no longer the case.

An explanation of this shift is apparent from Figure 10, which shows the distributions of public schools in 1975,1995 and 2006 in terms of average student SES 


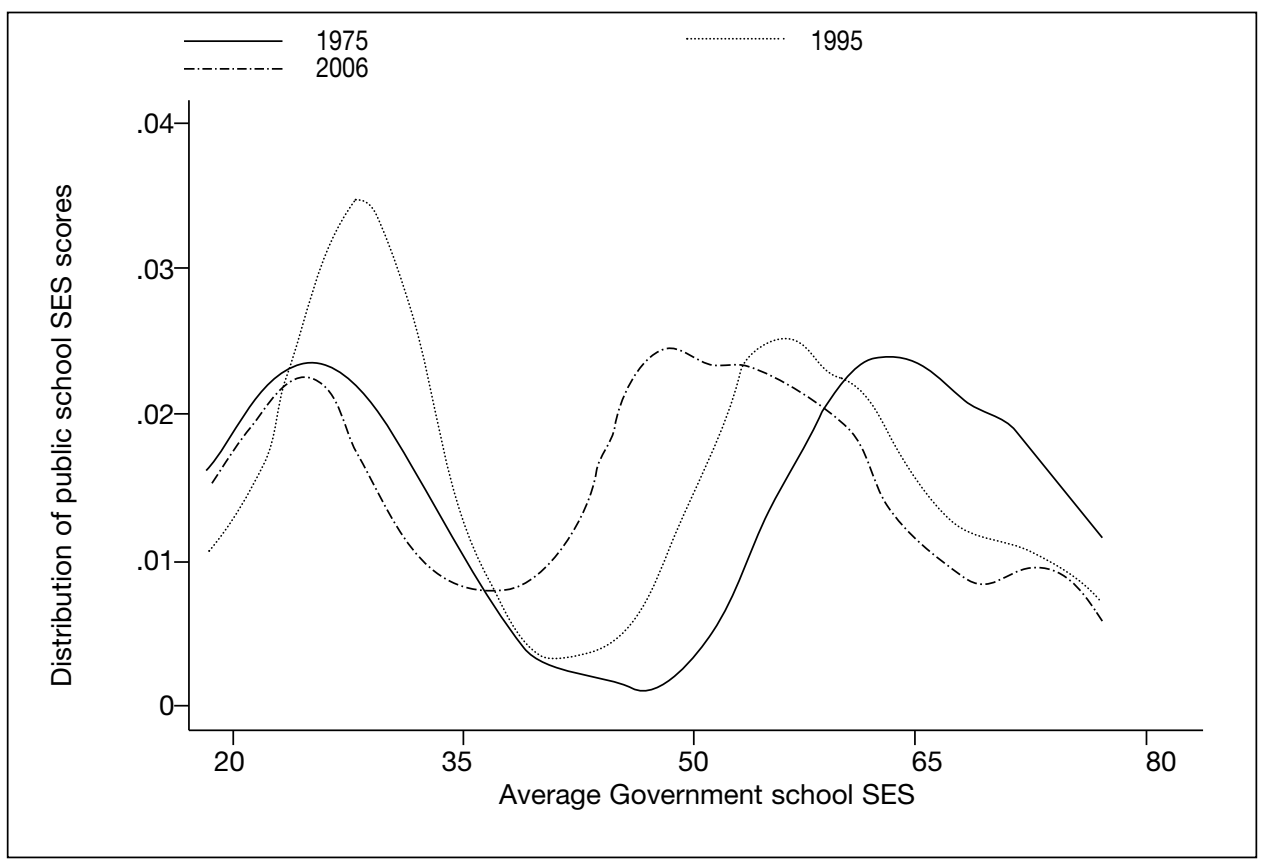

Figure 10 Distribution of public secondary schools by average SES: 1975, 1995 and 2006

Sources: Youth in Transition $196 \mathrm{I}$ birth cohort and the Longitudinal Surveys of Australian Youth 1995 and 2006 cohorts, Australian Council for Educational Research and the National Centre for Vocational Education Research, unpublished.

backgrounds. The 1975 distribution is clearly bimodal (has two peaks). There were two common 'types' of public schools in 1975: one with students with average SES backgrounds substantially below the average in the community and one just above the average. By 1995, a shift had taken place in the distribution of schools by their average SES background. The type of public schools with students with above average SES backgrounds had become less common and the once common 'high' SES public school was now only (just above) an average SES school. Consequently, students from the top half of the SES distribution, if they remained within the public sector, tended to go to schools with students who were predominantly from the lower half of the SES distribution. This has had the effect of increasing the average SES of the now more common 'low' SES type of public school. This 'trend' continued after 1995, with the higher peak shifting still further to the left in 2006, so that the peak of the 'high' SES public schools was now below the average SES.

In summary, the transfer of high SES students from public to private schools in Australia since 1975 has changed the average socio-economic composition of public secondary schools. The majority of students in public secondary schools now attend schools where the average socio-economic status of students is below average. The proportion of public secondary schools with concentrations of low-SES students (between the 20th and 40th SES percentiles) increased between 1975 and 2006. 


\section{Discussion}

The causal determinants of the shift in enrolments to the private sector are complex and we do not claim to offer a complete explanation of the dynamics of the Australian market for public and private schools. It is important to acknowledge the role of non-market factors that affect public and private schooling choices, such as parents' ideological (including religious) preferences, levels of household disposable income and the capacity of schools to meet individual student needs. While these factors may contribute to the drift from public to private schools, their impact can be overstated compared to the impact of government funding for both private and public schools. Official data demonstrate that private school enrolments were in steady decline in Australia during the 1960s before government subsidies were introduced and then increased steadily as subsidies from both federal and state governments flowed to private schools.

Researchers analysing the impact of private school funding schemes on student outcomes often refer to two factors that confound the stated intentions of such policy reforms: the strategies of private schools to select more desirable students, 'cream-skimming'; and different levels of motivation among parents to choose a school for their child (Levin, 1998). Thus, when governments create a market environment with the intention that schools will become more productive, both schools and parents are empowered to be 'choosers'. Some schools choose by selecting students from higher SES backgrounds while higher SES parents are also more likely to be choosers of schools that enrol such students. Evidence from Chile suggests that this has happened under its nationwide school voucher scheme (Hsieh \& Urquiola, 2003).

The evidence from Australia presented in this paper suggests that when operating subsidies are provided to private schools, parents from higher socioeconomic groups are more likely to choose private education than parents from lower socio-economic groups. This may be a result of higher SES families being less price-sensitive than lower SES families but could also be related to the perceived quality of private schools in terms of student:teacher ratios. The observation that families from higher SES backgrounds are more likely to be choosers is borne out by studies in other countries. Reviewing the empirical literature on school choice in England, Scotland, Belgium, and the USA, Levin concluded, 'those who exercise the choice option are more likely to be of higher SES and to have higher school achievement scores than those who continue to attend their assigned schools' (Levin, 1998, p. 379). Even when subsidies are restricted to families of low socioeconomic status, the families who exercise choice are more likely to be of higher SES than those who do not choose. Thus the activities of schools and the inactivity of some parents contribute to the apparent increase in socio-economic segregation between schools in an environment of market choice (Levin, 1998). It has been suggested that if targeted grant programs are to achieve their stated objectives of improving educational outcomes for disadvantaged students, they would have to randomly assign students to over-subscribed schools and deal with obstacles to choice such as transport costs and tuition fees (Ladd, 2002). 
We should not assume that all parents from all socio-economic backgrounds weigh up the costs and benefits of private schooling in the same way. To suggest that the act of choosing a child's school is purely an economic decision (that is, everyone buys the best that they can afford and those who can't afford anything simply choose the public system) is too simplistic. Obviously families take many factors into consideration when they choose a school and many parents prefer characteristics such as cultural diversity, secular values and community-based education in choosing their child's school. But the trends reported in this paper suggest that families from higher socio-economic groups have gained more benefit from Australia's funding scheme, in terms of expanded private school choice, than low-SES families.

This paper sheds light on how private schools choose to behave when they receive government subsidies. In receipt of increasing levels of government grants from the late 1960s and especially after 1974, private schools faced choices about how to use those funds, choices that would have quite different effects on the social composition of their student populations. For example, private schools could have either reduced fees while maintaining their existing level of school quality or maintained their fees at existing levels while using the increased funding to improve school quality. The first strategy - to reduce fees and maintain quality-would be the one most likely to have opened up participation in private schools to students from lower socio-economic backgrounds. As we have demonstrated, this is not how private schools in Australia responded to the introduction of student subsidies. Instead, they improved student:teacher ratios, which increased the quality of their schools. While this strategy meant that private schools could not reduce their tuition fees, it did not reduce demand for private schooling. To the contrary, it ensured that parents from higher socio-economic groups were the most likely to choose private schools over public schools. The clear 'losers' from the government funding scheme over the past four decades are the public school systems which now have schools with higher concentrations of lower SES students.

\section{Implications for policy}

The trends reported in this paper have implications for education policy and particularly for schools funding policies. The first implication is that we can expect to see a wide student achievement gap between public and private schools due to the lower average SES of students in the public school sector. It is well established that individual students' socio-economic backgrounds have a significant impact on their educational attainment (Rothman \& McMillan, 2003). As low-SES students now make up a higher proportion of public school populations, observed educational attainment levels in public schools can be expected to be lower-all else being equal-than observed levels of educational attainment in private schools. Governments will need to develop policies and programs for public schools to compensate for this gap, and should take these differences into account in publishing any public reports of student achievement that enables comparisons to be made between public and private schools. 
Governments should also be prepared for the impact of peer effects on students in public schools. Adverse peer effects generated by high concentrations of low-SES students in public schools can be expected to place further downward pressure on student performance in the public school system. Schools with low average-SES student populations are now more common in the public sector than they were in 1975 (Figure 10). Research suggests that the aggregate of student characteristics such as ability, motivation and aspirations represented by a school's average SES score produces a dominant ethos that influences individual student achievement in a variety of ways (Fuchs, Fuchs, Hamlett \& Karns, 1998; Hanushek, Kain, Markman \& Rivkin, 2001). We acknowledge that peer group characteristics do not offer a complete explanation of differences in school quality (see Lamb, Hogan \& Johnson, 2001) and that in-school programs and policies can have a positive effect on student learning outcomes. But, in the absence of targeted policy interventions to redress student composition effects, we would expect the rising number of public schools serving below-average SES student populations to have a compounding negative impact on individual student attainment levels in the public school sector.

Finally, the impact of high concentrations of low-SES students on public schools suggests that the cost of educating a student in a public school to an agreed standard will always be higher than in a private school. Public school systems also bear the additional costs of supporting small schools in rural areas and of accepting all students regardless of their attributes or residential location. The clear policy implication is that public school systems should be funded at a higher level per student than private schools. In other words, when governments set funding benchmarks for all schools, they should expect private schools to operate effectively at a lower level of resources per student than public schools. This is a reasonable assumption as long as private schools enrol a smaller proportion of low-SES students than public schools and are free of any expectations regarding universal provision.

\section{Conclusion}

The Australian experience offers sober lessons to policymakers in other countries contemplating the introduction of subsidies for private schools (for example, Gonzalez, Mizala \& Romaguera, 2004). Of particular note is our observation that private schools in Australia used increased government funding primarily to improve the quality of the learning experiences of students (measured here through improved student:teacher ratios), instead of reducing tuition fees. Not surprisingly, we found that the middle to top regions of the SES distribution was where most of the shift in students from the public to the private sector had taken place.

The loss of higher SES students has affected public schools substantially, with a relative fall in the number of public secondary schools enrolling students from above-average socio-economic backgrounds. To the extent that the peers of students have affected individual student achievement and other outcomes, this trend will contribute to rising costs per student in the public school sector. If the current funding system continues, Australia can expect to see a continuing drift 
of above-average SES students into the private school sector-a policy that will intensify the problems posed for public secondary schools of catering predominantly for students from lower SES backgrounds.

Proponents of greater school choice often advocate the explicit use of vouchers to facilitate the participation in private schools of students from low-SES backgrounds and argue that the value of these subsidies should be set at the level of resources per student provided to public schools (Buckingham, 2000; Neal, 2002). Our analysis suggests that private schools will not respond to the provision of even higher government subsidies any differently from the way in which they have for the past 40 years - they will leave their fees relatively unchanged and move to improve further the quality of their schooling, thus continuing to attract students from higher-SES backgrounds. The Australian experience illustrates how difficult it is to protect equity of access for students from lower socio-economic backgrounds under any grant scheme for funding private schools. Strong government regulation in respect of tuition fees and an independent mechanism governing the selection of students who receive government subsidies would be the minimum regulatory requirement for any funding system aiming to expand educational opportunities through supporting private school choice.

\section{Keywords}

education policy

socioeconomic influences

policy analysis

resource allocation educational finance

equal education

\section{References}

Albinski, H. S. (1966). The Australian Labor Party and the aid to parochial schools controversy. Pennsylvania: Pennsylvania State University Studies No. 19.

Australian Bureau of Statistics. (2008). Schools Australia. Catalogue No. 4221.0. Canberra: Australian Bureau of Statistics.

Buckingham, J. (2000). School funding for all: Making sense of the debate over dollars. Issue Analysis Paper No. 17. Sydney: Centre for Independent Studies.

Department of Education, Employment and Workplace Relations, Commonwealth (2009). Schools Assistance Act 2008. Administrative guidelines: Commonwealth programs for non-government schools, 2009 to 2012. Retrieved January 2010 from http://deewr. gov.au/Schooling/Programs/Pages/SchoolsAssistanceAct2008.aspx

Department of Employment, Education and Training, Commonwealth (1989). Commonwealth programs for schools, administrative guidelines 1989. Canberra: Australian Government Printing Office.

Dowling, A. (2008). 'Unhelpfully complex and exceedingly opaque': Australia's school funding system. Australian Journal of Education, 52(2), 129-150.

Fuchs, L. S., Fuchs, D., Hamlett, C. L., \& Karns, K. (1998). High-achieving students' interactions and performance on complex mathematical tasks as a function of homogeneous and heterogeneous pairings. American Educational Research Journal, 35(2), 227-267.

Gonzalez, P., Mizala, A., \& Romaguera, P. (2004, June). Vouchers, inequality and the Chilean experience. Research Paper. Santiago: Center for Applied Economics, University of Chile. 
Hanushek, E. A., Kain, J. F., Markman, J. M., \& Rivkin, S. G. (2001). Does peer ability affect student achievement? National Bureau of Economic Research Working Paper No. 8502. Cambridge, Massachusetts: National Bureau of Economic Research.

Hsieh, C. T., \& Urquiola, M. (2003). When schools compete, how do they compete? An assessment of Chile's nationwide school voucher program. National Bureau of Economic Research Working Paper No. 10008. Cambridge, Massachusetts: National Bureau of Economic Research.

Karmel, P. (Chair) (1973). Schools in Australia. Report of the Interim Committee for the Australian Schools Commission. Canberra: Australian Government Publishing Service.

Ladd, H. F. (2002). School vouchers: A critical view. Journal of Economic Perspectives, 16(4), $3-24$.

Lamb, S., Hogan, D., \& Johnson, T. (2001). The stratification of learning opportunities and achievement in Tasmanian secondary schools. Australian Journal of Education, 45(2), 153-167.

Levin, H. M. (1998). Educational vouchers: Effectiveness, choice and costs. Journal of Policy Analysis and Management, 17(3), 373-392.

Ministerial Council on Education, Employment, Training and Youth Affairs. (2004) National Report on Schooling in Australia. Melbourne: Author.

Mukerjee, D. (1999). Socio-economic status and school system enrolments. Australian Centre for Equity through Education. Retrieved 12 January 2010 from http://www.aeufederal.org.au/Publications/DMukherjeepaper.pdf

Neal, D. (2002). How vouchers could change the market for education. Journal of Economic Perspectives, 6(4), 25-44.

Preston, B. (2003). The social make-up of schools: Family income, religion, Indigenous status, and family type in government, Catholic and other nongovernment schools. Paper prepared for the Australian Education Union. Retrieved 12 January 2010 from http://www. aeufederal.org.au/Debates/bprestonsch.pdf

Radford, W. C., \& Wilkes, R. E. (1975). School leavers in Australia, 1971-1972. Melbourne: Australian Council for Educational Research.

Rothman, S., \& McMillan, J. (2003). Influences on achievement in literacy and numeracy. Longitudinal Surveys of Australian Youth Research Report No. 36. Melbourne: Australian Council for Educational Research.

Ruby, A., Wells, L., \& Wildermuth, C. (1995). Choice, market theory and education: What are we talking about? Occasional Paper No. 19. Canberra: Australian College of Education.

Ryan, C., \& Watson, L. (2004). The drift to private schools in Australia: Understanding its features. Discussion Paper No. 479. Centre for Economic Policy Research. Canberra: Australian National University.

Smart, D. (1978). Federal aid to Australian schools. Brisbane: University of Queensland Press.

Watson, L. (2003). A critique of the federal government's recent changes to private schools funding. Lifelong Learning Network Discussion Paper No. 3. Canberra: University of Canberra.

Watson, L. (2004). The total operating resources of Australian private schools in 2004. Lifelong Learning Network Discussion Paper No. 4. Canberra: University of Canberra.

Western, J. S. (1983). Social inequality in Australian society. Melbourne: Macmillan.

Williams, R. (1985). The economic determinants of private schooling in Australia. Economic Record, 61, 622-628. 


\section{Acknowledgements}

We are grateful to the Commonwealth Department of Education, Employment and Workplace Relations for the provision of unpublished aggregate school fee data and the Australian Council for Educational Research for the student-based data used in the paper. Chris Ryan acknowledges support for a project associated with this work from a research grant provided by the Australian Research Council (LX0883152). None of these bodies bears any responsibility for the manner in which we have interpreted the data or results.

\section{Authors}

Louise Watson is Associate Professor in the Faculty of Education, University of Canberra. Email: louise.watson@canberra.edu.au

Dr Chris Ryan is a Fellow in the Social Policy Evaluation, Analysis and Research Centre in the Research School of Economics, College of Business and Economics, Australian National University. 
Copyright of Full Text rests with the original copyright owner and, except as permitted under the Copyright Act 1968, copying this copyright material is prohibited without the permission of the owner or its exclusive licensee or agent or by way of a license from Copyright Agency Limited. For information about such licences contact Copyright Agency Limited on (02) 93947600 (ph) or (02) 93947601 (fax) 